\title{
The Effect of Transformational Leadership, Compensation and Self Efficacy Based on Job Satisfaction and Performance of Lecturers at Faculty of Veterinary Medicine, Airlangga University Indonesia
}

\author{
Arviadi Tri H. ${ }^{1}$, Murgianto ${ }^{2}$, Tri Andjarwati ${ }^{3}$ \\ Fakultas Ekonomi dan Bisnis Universitas 17 Agustus 1945 Surabaya \\ doi: 10.51505/IJEBMR.2022.6110 \\ URL: http://dx.doi.org/10.51505/IJEBMR.2022.6110
}

\begin{abstract}
The goal of this study was to see how transformational leadership, compensation, and selfefficacy affected job satisfaction and performance among education personnel at Airlangga University in Surabaya's Faculty of Veterinary Medicine. The quantitative research method was applied in this study. This study's sample consisted of 65 people who were polled utilizing the Non Probability approach. Data was gathered by handing out questionnaires containing multiple statements. While the data utilized in this study was technical analyzed using Partial Least Squares (PLS).
\end{abstract}

Keywords: Transformational Leadership, Compensation, Self Efficacy, Job Satisfaction, Performance.

\section{Introduction}

Understanding organizational behavior entails comprehending the conduct of individual and group members of the organization. Understanding human behavior is challenging since each individual human being has a unique personality. Similarly, environmental circumstances, history, experience, abilities, and other elements all influence human behavior. The focus of organizational behavior is on how to get people habituated to working in groups. Individual work is better to team work, and organizations of all types and sizes interact with their internal and external environments. Robbins, et al (2011:10), organizational behavior (organizational behavior) is a field of study that investigates the impact of individuals, groups, and structures on organizational behavior, with the goal of applying knowledge to improve an organization's effectiveness.

There is no transformative leadership that sets an example for staff to work responsibly, which has an impact on faculty performance. Compensation has an impact on educational personnel's performance as well. For example, when education personnel's workloads change, the incentives they receive are consistent month after month or there is no discernible variation. Some educational personnel may be less productive in their profession as a result of the salary they get. On the other hand, according to data from the Airlangga University cyber campus, the number of new students has decreased during the last five years (2016-2020). Based on the statistics above, the graph depicts a reduction in the number of new students for the 2016 - 2020 period. 
Vol. 6, No.01; 2022

ISSN: $2456-7760$

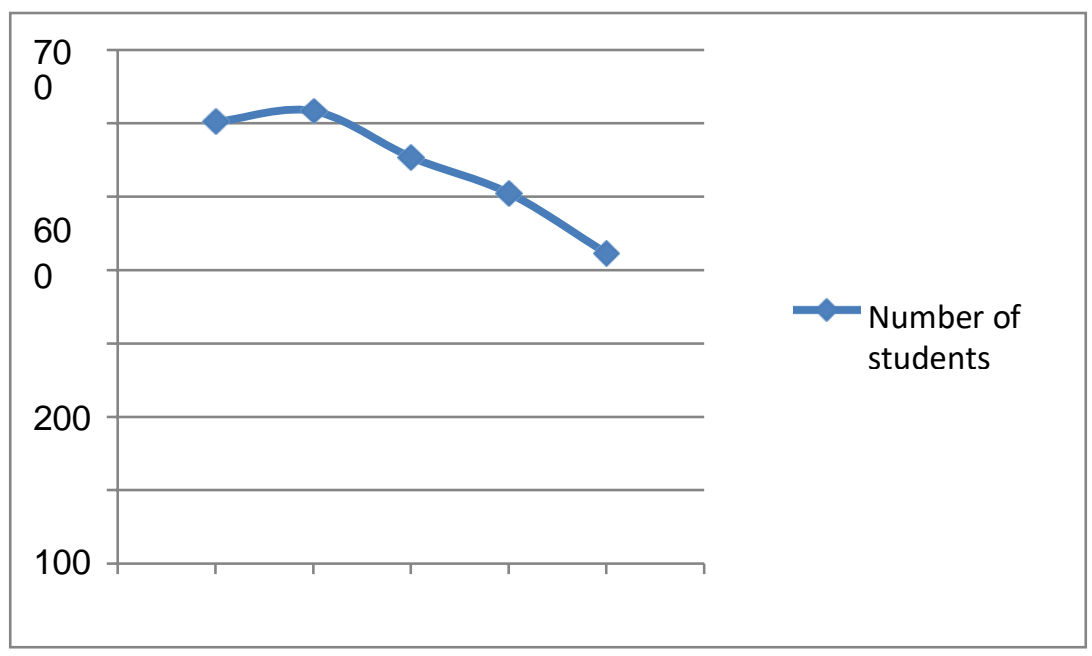

Picture 1

New Students of the Faculty of Veterinary Medicine, Universitas Airlangga for the period $2016-2020$

One technique to assess an employee's efficacy is to look at their performance. "Employee performance is the consequence of work in quality and quantity that has been achieved by an employee in carrying out his duties in line with the obligations provided to him," according to Anwar Prabu Mangkunegara (2012: 67). Transformational leadership, remuneration, and selfefficacy all have a strong link to performance and job happiness. Educational workers who are happy with their jobs will produce high-quality work and remain loyal to the school. Job satisfaction, according to Robbins (2015: 170), is defined as "the gap between the amount of compensation received by workers and the amount of compensation that is considered to be received." Transformational leadership, or the leader's ability to build working relationships with people in the organization in order to promote job satisfaction between employees and their leaders, is one of the elements that influence job happiness. Yulk (2010:305) defines transformational leadership as one in which subordinates have a sense of trust, loyalty, and respect for the leader, and are inspired to go above and beyond their expectations. Compensation factor is one of the most important functions in human resource management (HRM) and one of the most sensitive aspects in working relationships that helps in strengthening the organization's key values and facilitating the achievement of institutional organizational goals, in addition to transformational leadership. Compensation, according to Hasibuan (2017:119), is all money, products, and services received by employees in exchange for services rendered to institutions. 


\section{International Journal of Economics, Business and Management Research}

Vol. 6, No.01; 2022

ISSN: $2456-7760$

Apart from transformational leadership and salary, self-efficacy is another aspect that influences employee job satisfaction. Employees are required to have a high level of self-efficacy at work, often known as self-efficacy. Self-efficacy, according to Kreitner and Kinicki (2005: 79), is a person's belief in his ability to complete a task successfully. The researcher wishes to do more research on "The Influence of Transformational Leadership, Compensation, and Self-efficacy on Job Satisfaction and Performance of Education Personnel at the Faculty of Veterinary Medicine, Airlangga University" based on the preceding statement.

\section{Research Problem:}

1. Does transformational leadership affect the job satisfaction of education personnel at Universitas Airlangga's Faculty of Veterinary Medicine?

2. Does salary affect the job satisfaction of education employees at Universitas Airlangga's Faculty of Veterinary Medicine?

3. Does self-efficacy affect the job satisfaction of education staff at Universitas Airlangga's Faculty of Veterinary Medicine?

4. Does transformational leadership affect the effectiveness of education employees at Universitas Airlangga's Faculty of Veterinary Medicine?

5. Does salary affect the effectiveness of education staff at Universitas Airlangga's Faculty of Veterinary Medicine?

6. Does self-efficacy affect the performance of education professionals at Universitas Airlangga's Faculty of Veterinary Medicine?

7. Does work satisfaction affect the performance of education staff at Universitas Airlangga's Faculty of Veterinary Medicine?

\section{Literature Review}

\section{Transformational leadership}

Good leadership has implications for moral action in responding to one's values and needs in a way that is conducive to building human relations, according to Armstrong and Taylor (2014: 644). Transformational leadership includes activities to motivate people to work hard in achieving big goals; good leadership has implications for moral action in responding to one's values and needs in a way that is conducive to building human relations. According to Yulk (2010:305), transformational leadership occurs when subordinates have a sense of trust, loyalty, and respect for the leader, and subordinates are inspired to achieve more than they expect. The findings of Kosasih, A. (2018) research have a direct impact on transformational leadership and job satisfaction among employees.

\section{Compensation}

According to Handoko (2014: 155), compensation is anything that employees receive in return for their work. Hasibuan $(2012,118)$ said that compensation can be divided into two, namely Direct Compensation in the form of Salary, Wages, Incentive ages, while Indirect Compensation is in the form of benefits services. Hasibuan (2014: 118) All pay earned by employees in the form of money, direct goods, or indirect goods in exchange for services rendered to the company is referred to as compensation. "Compensation is something that is considered equal," 


\section{International Journal of Economics, Business and Management Research}

Vol. 6, No.01; 2022

ISSN: $2456-7760$

Mangkunegara (2011: 83) explains. Gifts in the form of money are bonuses provided to workers in recognition of their service in the workplace. According to Musriha, M. (2019) study, compensation has a major impact on results.

\section{Self Efficacy}

Employees' self-efficacy refers to their belief in their capacity to complete things correctly. Selfefficacy is defined by Bandura (2006:199) as a person's belief that he or she can master a situation and achieve favorable outcomes. Kaswan is a character in the film Kaswan (2011:30) Self-efficacy is a person's assessment of his or her ability to learn new information or abilities. Self-Efficacy positively and significantly increases job satisfaction of Inna Grand Bali Beach Hotel employees, according to research done by Parasara, IBAI, and Surya, IBK (2016). The higher the Self-Efficacy, the better the job satisfaction of Inna Grand Bali Beach Hotel employees. Hotel

\section{Job satisfaction}

Robbins (2015: 170) stated that job satisfaction is a general attitude towards one's job as the difference between the amount of reward received by workers and the number of tips to be accepted. Job satisfaction is an essential thing that individuals have at work. Each worker has different characteristics, so the level of job satisfaction is also different - the story of job satisfaction is also different - the level of job satisfaction is different. Job satisfaction, according to Wibowo (2017: 170), is defined as the difference between the number of incentives earned by employees and the number of incentives that should be received. According to Edy Sutrisno (2014: 75), job satisfaction is a fun or negative emotional condition that employees experience when they look at their jobs. Job satisfaction is a measure of a person's feelings towards his or her job. Murgianto, S. S. Suhermin. (2016) also found that the work satisfaction indicator has a substantial impact on the East Java Integrated Service Office's employee success.

\section{Performance}

Performance is the result of work and work behavior that has been achieved in completing assigned tasks and responsibilities within a certain period. Anwar Prabu Mangkunegara (2014: 67) states that performance results from work in quality and quantity achieved by a worker given to him. Mulyadi (2015: 63) describes success as the quality and quantity of work completed by employees in accordance with their duties and responsibilities. Wibowo's (2013: 7) success is the product of work that is closely linked to organizational strategy, customer loyalty, and economic contribution.

\section{Conceptual Framework}

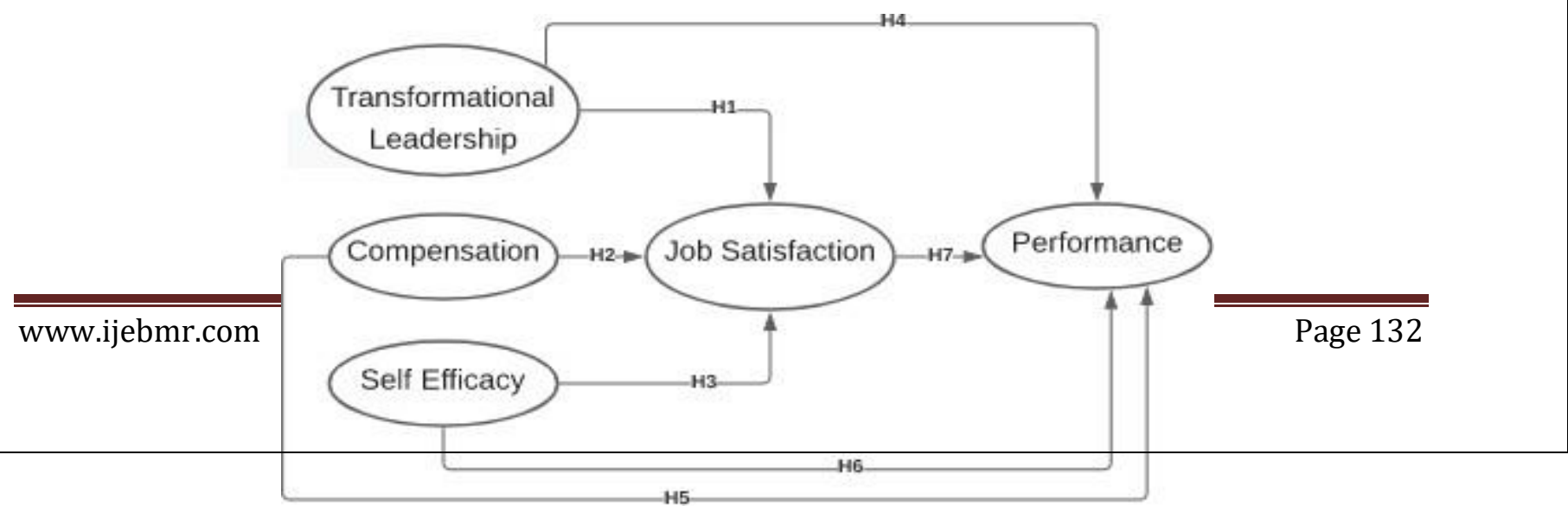


Vol. 6, No.01; 2022

ISSN: $2456-7760$

Picture 2 Conceptual Framework

\section{Research Hypothesis}

H1 = Transformational leadership has an impact on the job satisfaction of education employees at Airlangga University in Surabaya's Faculty of Veterinary Medicine.

$\mathrm{H} 2$ = Compensation has an impact on the job satisfaction of education personnel at Airlangga University in Surabaya's Faculty of Veterinary Medicine.

H3 = The impact of self-efficacy on job satisfaction among education personnel at Airlangga University in Surabaya's Faculty of Veterinary Medicine.

H4 = The performance of education personnel at Airlangga University's Faculty of Veterinary Medicine in Surabaya is influenced by transformational leadership.

$\mathrm{H} 5=$ Compensation influences the performance of education staff at Airlangga University in Surabaya's Faculty of Veterinary Medicine.

H6 = The performance of education staff at the Faculty of Veterinary Medicine, Airlangga University, Surabaya Universitas, is influenced by self-efficacy.

H7 = Job satisfaction influences the performance of education staff at Airlangga University in Surabaya's Faculty of Veterinary Medicine.

\section{Research Methods}

Research Design

The approach used in this research is quantitative. The sampling technique in this study uses the Non-Probability technique. The population in this study is the educational staff at the Faculty Of Veterinary Medicine of Airlangga University, which consists of 65 people comprised of Civil Servants (PNS). The data collection method was discovered via the distribution of questionnaires. A Likert scale with five response categories was used to measure Transformational Leadership variables (X1), Compensation variables (X2), Self Efficacy variables (X3), job satisfaction variables (Z), and Performance variables (Y). The Structural Equation Model (SEM) method based on Partial Least Squares was used to test the study hypothesis (PLS).

\section{Results and Discussion}

A. Evaluation of the Outer Model

Evaluation of the measurement model is a stage to evaluate the validity and reliability of construct validity evaluation and construct reliability evaluation. In this study, the researcher determined that there were seven problem formulations with five variables, namely Transformational Leadership (X1), Compensation (X2), Self Efficacy (X3), Job Satisfaction (Z), and Performance (Y). Each will be explained as follows: 
Vol. 6, No.01; 2022

ISSN: $2456-7760$

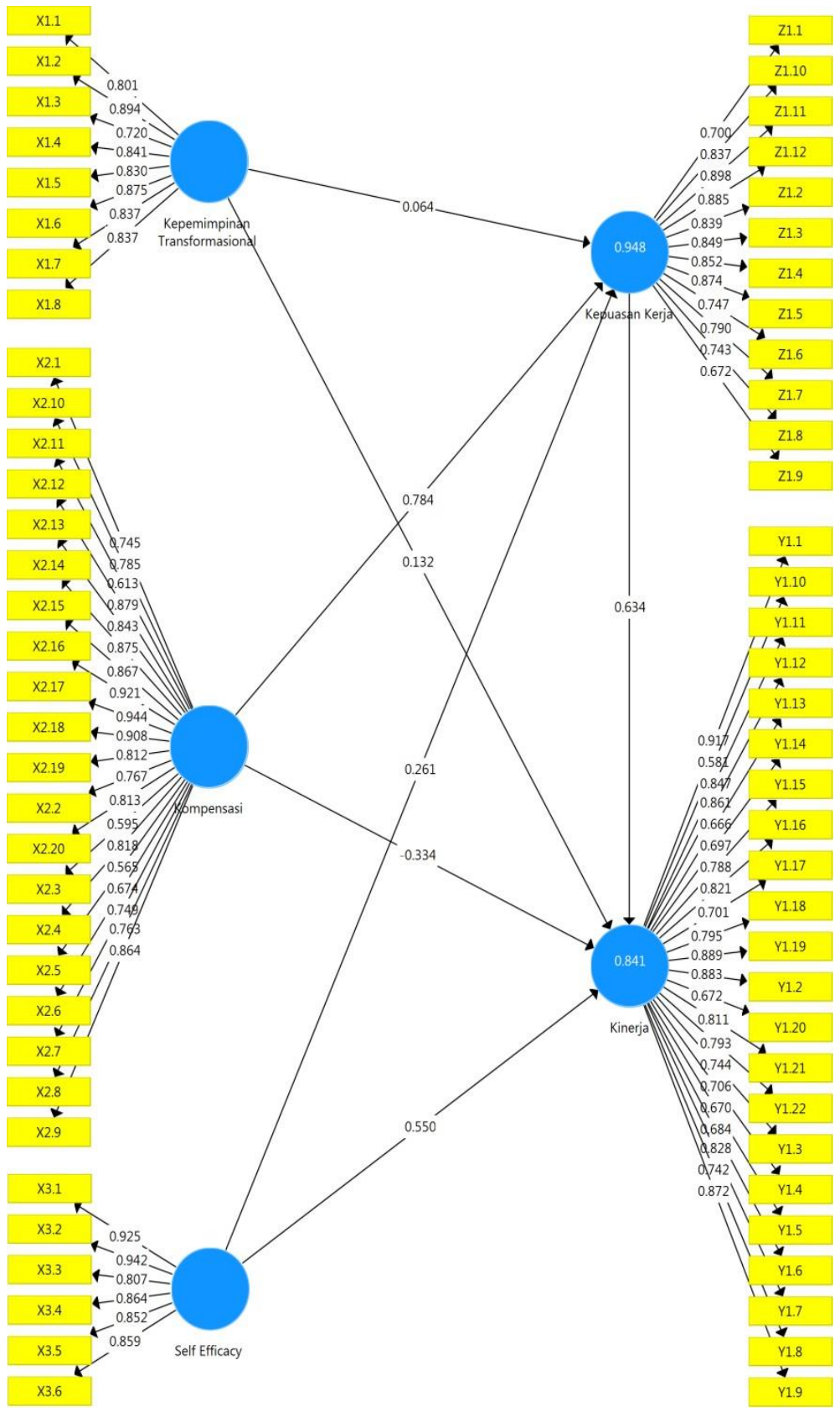

Picture 3 Construct of the Outer Model

\section{B. Composite Reliability}

The reliability value of indicators in a build is tested using composite reliability. If a constructor variable has a composite reliability value greater than 0.5 , it is said to meet composite reliability. The composite reliability value for each build/variable is listed below 


\begin{tabular}{|l|c|c|c|}
\hline \multicolumn{1}{|c|}{$\begin{array}{l}\text { Cariable } \\
\text { s }\end{array}$} & symbols & Value & Description \\
\hline Job satisfaction & $\mathrm{Z}$ & 0.958 & Reliable \\
\hline Performance & $\mathrm{Y}$ & 0.971 & Reliable \\
\hline Transformational Leadership & $\mathrm{X} 1$ & 0.947 & Reliable \\
\hline Compensation & $\mathrm{X} 2$ & 0.972 & Reliable \\
\hline Self Efficacy & $\mathrm{X} 3$ & 0.952 & Reliable \\
\hline
\end{tabular}

\section{Average Variance Extracted (AVE)}

The higher the average variance extracted (AVE) value, the stronger the association between the variables' indicators. In the table below, you can see the average variance extracted (AVE) value for each element.

\section{Nilai AVE}

\begin{tabular}{|l|c|c|}
\hline \multicolumn{1}{|c|}{ Variable } & AVE & Description \\
\hline Job satisfaction & 0.657 & $>0,50$ \\
\hline Performance & 0.603 & $>0,50$ \\
\hline Transformational Leadership & 0.690 & $>0,50$ \\
\hline Compensation & 0.635 & $>0,50$ \\
\hline Self Efficacy & 0.768 & $>0,50$ \\
\hline
\end{tabular}

\section{Hypothesis Testing}

Table 1 Effects between Research Constructs

\begin{tabular}{|l|c|c|c|c|c|}
\hline \multicolumn{1}{|c|}{ Variable Relationships } & $\begin{array}{c}\text { Path } \\
\text { Coefficient }\end{array}$ & $\begin{array}{c}\text { Standart } \\
\text { Error }\end{array}$ & $\begin{array}{c}\boldsymbol{T} \text { - } \\
\text { Statistic }\end{array}$ & $\begin{array}{c}\boldsymbol{P} \text { - } \\
\text { value }\end{array}$ & Information \\
\hline $\begin{array}{l}\text { Transformational } \\
\text { LeadershipJob } \\
\text { satisfaction }\end{array}$ & 0,064 & 0,056 & 1,142 & 0,254 & No effect \\
\hline $\begin{array}{l}\text { Compensation Job } \\
\text { satisfaction }\end{array}$ & 0,784 & 0,047 & 16,831 & 0,000 & Take effect \\
\hline $\begin{array}{l}\text { Self EfficacyJob } \\
\text { satisfaction }\end{array}$ & 0,261 & 0,057 & 4,554 & 0,000 & Take effect \\
$\begin{array}{l}\text { Transformational } \\
\text { Leadership Peformance }\end{array}$ & 0,132 & 0,102 & 0,295 & 0,195 & No effect \\
\hline Compensation Performance & $-0,334$ & 0,300 & 1,114 & 0,266 & No effect \\
\hline Self Efficacy Performance & 0,550 & 0,134 & 4,095 & 0,000 & Take effect \\
\hline Job satisfaction Performance & 0,634 & 0,338 & 1,875 & 0,061 & No effect \\
\hline
\end{tabular}

\section{E. Discussion}

1. Job satisfaction is unaffected by transformational leadership. The link between Transformational Leadership and Job Satisfaction is investigated in Hypothesis 1. Ho is accepted 


\section{International Journal of Economics, Business and Management Research}

Vol. 6, No.01; 2022

ISSN: $2456-7760$

because transformational leadership (X1) has an effect of 0.064 , a t-statistic of $1.412(<1.96)$, and a p-value of 0.254 (>0.05), implying that transformational leadership (X1) has no effect on job satisfaction (Z). This is consistent with Diansyah, D. (2018), who found that transformational leadership has a negligible impact on employee job satisfaction, with a $\mathrm{T}$ statistic value of 0.720 $<1.96$ and a $\mathrm{P}$ value of $0.472<0.05$.

Transformational leadership has no effect on job satisfaction of educational staff at the Faculty of Veterinary Medicine, Airlangga University, Surabaya

"Idealized Influence. (Influence of Idealism)" is the greatest indication result for transformational leadership. The statement "The supervisor is a role model for carrying out work according to SOP and the superior has a vision for institutional development" had an average score of 4.48. It can be concluded that transformational leadership has no impact on job satisfaction because the education staff follows the SOP and the transformational leadership in the Faculty of Veterinary Medicine has not fully considered the abilities and strengths of individual education personnel in carrying out their duties. For example, the task assigned is only confined to daily routines, so if problems arise that demand immediate resolution without the involvement of third parties, the leadership has not placed full trust in the education staff.

2. Job satisfaction is influenced by compensation. The second hypothesis investigates the link between pay and job satisfaction. Compensation has an effect of 0.784 using the SEM PLS approach, with a t-statistic of $16.931(>1.96)$ and a p-value of $0.000(0.05)$, indicating that compensation (X2) has an effect on work satisfaction (Z). This research supports Sudiarditha, IKR, Susita, D., and Kartini, TM (2019), who found that compensation for job satisfaction had a $\mathrm{t}$-value of 3.81>1.96, indicating that remuneration has a positive and significant effect on job satisfaction, which can increase employee performance.

Compensation affects the job satisfaction of education staff at the Faculty of Veterinary Medicine, Airlangga University, Surabaya

"Employees' attitudes about holiday allowances provided by the institution" had the highest compensation indicator result, with an average score of 4.41, based on the statement "I get vacation allowances every year and the quantity of holiday allowances provided by the institution is adequate." The statement "The agency gives me leave and the option for leave supplied by the institution is in compliance with existing regulations" received the second highest score of 4.16 from the employee assessment indicator on work leave. The results of respondents' responses show that remuneration has an effect on job satisfaction, as evidenced by the fact that the yearly holiday allowance is suitable and the institution is highly concerned about educational personnel on leave opportunities in compliance with applicable legislation.

3. Job satisfaction is influenced by self-efficacy. Hypothesis 3 investigates the link between job satisfaction and self-efficacy. When self-efficacy has a 0.261 effect, a t-statistic of 4.554 (> 1.96), and a p-value of $0.000(<0.05)$, Ho is rejected, indicating that self-efficacy has an impact on job satisfaction. This is in line with the findings of Ida, P. I. A. B., and Ida, S. K. B. (2016), 


\section{International Journal of Economics, Business and Management Research}

Vol. 6, No.01; 2022

ISSN: $2456-7760$

who found that the value of Sig. $t$ is 0.000 with a beta coefficient of 0.365 after analyzing the influence of self-efficacy on employee work satisfaction. The Sig. $t$ value is $0.000<0.05$.

Self Efficacy affects the job satisfaction of education staff at the Faculty of Veterinary Medicine, Airlangga University, Surabaya

Efficacy in Oneself The statement "I have confidence in my talents in any circumstance at work and am able to take responsibility for my work" received the highest indicator result, with an average score of 4.37. It may be concluded that, despite the complexity of their task, education employees have confidence in their talents, competencies, and associated mastery, and that they are satisfied with their work.

4. Performance is unaffected by transformational leadership. This fourth hypothesis is supported by data analysis, which revealed that Transformational Leadership has an effect of 0.132 , a tstatistic of $0.295(<1.96)$, and a p-value of $0.195(>0.05)$, implying that transformational leadership has no influence on performance. This research supports Anjarwati, T. (2018), who claims that Transformational Leadership has no effect on cooperative performance in Surabaya, with a P-value of0.991.

Transformational leadership has no effect on the performance of education staff at the Faculty of Veterinary Medicine, Airlangga University, Surabaya

The statement "The supervisor is a role model to carry out work according to the SOP and the superior has a vision for institutional development" has the highest indicator result of "Idealized Influence. (Influence of Idealism)" with an average score of 4.48. It can be argued that transformational leadership has no effect on performance because educational personnel can operate independently and there is a clear work schedule and standard operating procedure (Standard Operational Procedure). Furthermore, because education workers execute the same and routine tasks, transformational leadership has no effect on their performance.

5. Performance is unaffected by compensation. This fifth hypothesis is supported by data analysis, which indicated that compensation has a -0.334 effect, a t-statistic of 1.114 (1.96), and a p-value of $0.266(>0.05)$, indicating that compensation has no influence on performance. With a coefficient value of 0.049 and a t-statistic of 0.849, Saputra, P., Sudiro, A., and Irawanto, D. W. (2018) claim that compensation has no meaningful effect on performance.

Compensation has no effect on the performance of education staff at the Faculty of Veterinary Medicine, Airlangga University, Surabaya

The statement "I obtain overtime pay according to the excess hours worked and I get a proper award for the work I conduct outside working hours" yields the lowest compensation indicator result of "Overtime pay according to the length of overtime" with an average score of 3.69. It can be inferred that remuneration has no impact on performance. This is because educational personnel receives overtime pay that is not proportional to their workload, causing certain educational employees to be less productive in their work. 


\section{International Journal of Economics, Business and Management Research}

Vol. 6, No.01; 2022

ISSN: $2456-7760$

6. The level of self-efficacy has an impact on performance. Because the data analysis revealed thatSelfEfficacyhadanimpactof0.550, at-statisticof4.095(>1.96), and ap-value of

$0.000(<0.05)$, Ho is rejected, implying that self-efficacy has an influence on performance. According to Harjono, GJ, Lumanauw, B., \& Caesar, K. (2015), the self-efficacy variable has a t count value of 3.068 with a $p$ value of 0.003 , and the $t$ table has a significance level of 5\%, the $t$ table is $=198698$. $\mathrm{H} 3$ is acceptable since $\mathrm{t}$ count $>\mathrm{t}$ table $(3.068>1.98698)$ with sig

$<0.05$. This suggests that employee performance is statistically influenced by self-efficacy. Self Efficacy affects the performance of education staff at the Faculty of Veterinary Medicine, Airlangga University, Surabaya

The lowest indicator performance variable is "Ability" with an average score of 4.04 through the statement "I have the skills to be applied in my work and I am able to operate every eq," while the lowest indicator performance variable is "Generality" with an average score of 4.14 through the statement "I have perseverance in achieving goals and I believe I can survive when facing obstacles at work," while the lowest indicator performance variable is "Ability" with an average score of 4.04 through the statement "I have the skills to be It can be concluded that poor scores for indicators of generality (breadth) and proficiency are attributable to a lack of institutional attention to educate staff in increasing performance, such as providing training to increase work skills.

7. Job satisfaction has no bearing on productivity. Because the findings of the data analysis revealed that job satisfaction has an effect of 0.634, a t-statistic of 1.875 (1.96), and a p-value of 0.061 (>0.05), Ho is accepted, implying that job satisfaction has no effect on performance. According to Adiyasa, NIW, \& Windayanti, W. (2019), job satisfaction is known to result in a tcount of (-1.482) ttable, namely (2.019) with Sig of $(0.146)>(0.05)$, it can be determined that $\mathrm{Ha} 2$ is rejected and $\mathrm{Ho} 2$ is accepted, implying that the job satisfaction variable (X2) partially has no significant effect on the employee performance variable.

Job satisfaction has no effect on the performance of education staff at the Faculty of Veterinary Medicine, Airlangga University, Surabaya

With an average score of 3.76, the lowest indicator of job satisfaction is "Salary / Wages (Pay)," which is expressed as "The salary I receive is currently satisfactory, in accordance with the workload and responsibilities that I perform, and I can live worthy of the benefits I receive from the institution." It may be inferred that job happiness has no impact on performance. This is due to the fact that one of the most essential responsibilities that receives a low grade is allowances, which is one of the most crucial supports in encouraging educational personnel to work more. However, because the allowances offered at this time do not correspond to the current workload, the allowances given to education employees have little impact on job satisfaction. 


\section{International Journal of Economics, Business and Management Research}

Vol. 6, No.01; 2022

ISSN: $2456-7760$

\section{F. Conclusion}

1. Educational staff follows SOPs, and transformational leadership at the Faculty of Veterinary Medicine has not paid enough attention to individual education personnel's abilities and strengths in carrying out their jobs.

2. The holiday stipend received annually is appropriate, and the institution is highly concerned about educational personnel on leave opportunities in compliance with applicable legislation, as evidenced by the responses of respondents.

3. Even when they face a level of difficulty, educational professionals have confidence in their talents, competencies, and related mastery in their work, resulting in satisfaction in their employment.

4. Educational staff can work freely, and there is a clear work plan and standard operating procedure in place (Standard Operational Procedure). Furthermore, because educational staff execute the same and routine tasks, transformational leadership has no effect on their performance.

5. Educational personnel receives compensation in the form of overtime money that does not correspond to the workload, causing some educational employees to be less productive in their work.

6. According to the indicators of generality (breadth) and ability to achieve a low evaluation, this is due to a lack of institutional attention to education people in increasing performance, such as offering training to improve work skills.

7. As a result, the allowances offered to education professionals have little effect on job satisfaction because the benefits supplied are currently not in accordance with the existing workload.

\section{G. Recommendation}

1. Transformational Leadership: In carrying out their duties in accordance with their capabilities, leaders must pay close attention to the abilities and strengths of individual education workers.

2. Compensation: it is required to hold trainings in accordance with their field of work in order to improve the abilities of education employees.

3. Job satisfaction: job satisfaction can be improved by offering incentives based on the workload of educators.

\section{H. References}

Mangkunegara. 2012. Human Resource Management. Bandung: PT. Remaja Rosdakarya. Anjarwati. 2018. The Influence of Transformational Leadership and Innovation on Entrepreneurship Orientation and Cooperative Performance in Surabaya. Journal of Shipping and Port Applications, 8(1), 78-84. 


\section{International Journal of Economics, Business and Management Research}

Vol. 6, No.01; 2022

ISSN: $2456-7760$

Armstrong, et al. 2014. Armstrong's Handbook of Human Resource Management Practice. Kogan Page.

Adiyasa, Windayanti. 2019. The Influence of Motivation, Job Satisfaction, and Leadership on Employee Performance at PT. XYZ. Journal of Strategic Management and Business Applications, 2(1), 23-30.

Bandura, A. 2006. Guide for Constructing Self-Efficacy Scales in Frank Pajares\& Tim Urdan (Ed.), Self-Efficacy Beliefs of Adolescents. Greenwich: Information Age Publishing.

Diansyah. 2018. The Effect of Transformational Leadership and Compensation on Job Satisfaction Through Organizational Commitment. Media Economics and Management,33 (1).

Edy, Sutrisno, 2016, Human Resource Management, Kencana Prenada Media Group, Jakarta. Hasibuan, Malayu. 2014.Human Resource Management. Jakarta: Bumi Aksara Hasibuan.

Handoko, T.Hani. 2014. Personnel Management \& Human Resources. Second Edition. Yogyakarta: BPFE-Yogyakarta.

Harjono, et al. 2015. The Influence of Transformational Leadership and Self-efficacy on the Performance of PT. Manado Water. EMBA Journal: Journal of Economic Research, Management, Business and Accounting,3(3).

Ida, Ida. 2016. The Effect of Self-efficacy on Motivation and Job Satisfaction of Inna Grand Bali Beach Hotel Employees. Journal of Management Unud, 5(5), 4219- 3247 Kaswan, 2011, Training and Development to Improve HR Performance, first edition. Jakarta: CV. Alfabeta.

Kreitner, Kinicki. 2005. Organizational Behaviour. Jakarta: Salemba Empat.

Kosasih. 2018. The Influence of Transformational Leadership, Organizational Culture and Employee Motivation on Employee Job Satisfaction and Its Implications for PDAM Employee Performance in Banten Province. Journal of Government and Civil Society, 1(2), 159-190.

Sudiarditha, et al. 2019. Compensation and Work Discipline On Employee Performance With Job Satisfaction As Intervening. Trikonomika, 18(2), 27-34.

Saputra, et al. 2018. Job satisfaction in compensation, environment, discipline, and performance: evidence from Indonesia higher education. MEC-J (Management and Economics Journal), 2(3), 217-236.

Murgianto, Suhermin. 2016. The Effects Of Commitment, Competence, Work Satisfaction On Motivation, And Performance Of Employees At Integrated Service Office Of East Java. International Journal of Advanced Research, 3(1), 378-396

Mulyadi. 2015. Organizational Behavior and Service Leadership. First Edition.

Bandung: Penerbit Alfabeta.

Robbins, Judge. 2015. Organization Behaviour, Fifteenth Edition, Jakarta: Penerbit Salemba Empat. 
International Journal of Economics, Business and Management Research

Vol. 6, No.01; 2022

ISSN: $2456-7760$

Wibowo. 2017. Work management. Third Edition. Jakarta: PT. Raja Grafindo Persada. Wibowo, 2013. Organizational Behaviour. Jakarta: Rajawali Pers.

Yulk, Gery. 2010. Organizational Leadership. Fifth Edition. Jakarta: PT. Indeks. 